\title{
Geo(Im)pulse
}

\section{Bird remains from the Maastrichtian type area (Late Cretaceous)}

\section{G.J. Dyke ${ }^{1, *}$, A.S. Schulp ${ }^{2} \&$ J.W.M. Jagt ${ }^{2}$}

1 School of Biology and Environmental Sciences, University College Dublin, Belfield, Dublin 4, Ireland.

2 Natuurhistorisch Museum Maastricht, De Bosquetplein 6-7, NL-6211KJ Maastricht, the Netherlands.

* Corresponding author. Email: gareth.dyke@ucd.ie

Manuscript received: June 2007; accepted: October 2008

\begin{abstract}
Remains of Late Cretaceous birds are rare, which is especially true for Europe and the type area of the Maastrichtian Stage (southeast Netherlands, northeast Belgium) in particular. In the present paper, we record new remains (isolated tarsometatarsus and radius) that document the presence of both enantiornithine and ornithurine birds in the Maastrichtian area. These fossils, although fragmentary, are important in view of their stratigraphic age: all bird remains discovered to date in the Maastricht area are amongst the youngest 'non-modern' avians known, originating from strata deposited less than 500,000 years prior to the end of the Cretaceous Period.
\end{abstract}

Keywords: Aves, Enantiornithes, Ornithurae, Maastrichtian, Late Cretaceous, the Netherlands, Belgium

\section{Introduction}

Despite more than 250 years of intensive collecting effort in shallow marine sediments in the type area of the Maastrichtian Stage (southeast Netherlands, northeast Belgium; Fig. 1), the first bird remains to be recognised from this part of Europe have been described only relatively recently. Dyke et al. (2002) recorded a partial forelimb skeleton of a large ornithurine bird, closely related to the well-known North American genus Ichthyornis (see Marsh, 1880; Clarke, 2004). The discovery of a marine, possibly diving, bird in these sediments is no surprise - the bulk of the vertebrate fauna from the Maastrichtian type area comprises marine forms, with the exception of rare occurrences of washed-in, dissociated hadrosaurid dinosaur bones (Jagt et al., 2003; Mulder et al., 2005) and of a single isolated tooth of a marsupial (Martin et al., 2005). What is surprising, is that it took so long for a bird fossil to be uncovered, since local collectors routinely examine bulk samples from these strata, down to mesh widths of $0.3 \mathrm{~mm}$. Now that birds have been recognised and described, we can only hope that more will be forthcoming.
In general, the fossil record of birds from the latest stages of the Cretaceous is more scanty and less well understood than that of the Lower and 'Middle' Cretaceous (Chiappe \& Dyke, 2002; Chiappe \& Witmer, 2002; Fountaine et al., 2005). In particular, Late Cretaceous birds are rare in Europe (see Dyke et al., 2002; Rees \& Lindgren, 2005): the bulk of the material now known is either from the Lower or 'Middle' Cretaceous. Thus, any additional fossils from the Maastricht area document an important fully-marine avifauna very close to the Cretaceous-Paleogene ( $\mathrm{K}-\mathrm{Pg}$ ) boundary, and add data to the ongoing debate surrounding the apparently 'selective' survivorship of modern birds (Neornithes) across this extinction horizon (Chiappe \& Dyke, 2002; Dyke et al., 2007).

In this short note, we describe and discuss two additional specimens of latest Cretaceous birds from the Maastrichtian type area that are referable to the avian clades Enantiornithes and Ornithurae (Fig. 2). On account of the fact that the bones available are incomplete, few characters support these assignments, which is why we have limited ourselves to features utilised in previous phylogenetic analyses. Nevertheless, the enantiornithine lineage (Fig. 2) is the most diverse clade yet known of small Mesozoic flying birds (Walker, 1981; Chiappe \& 

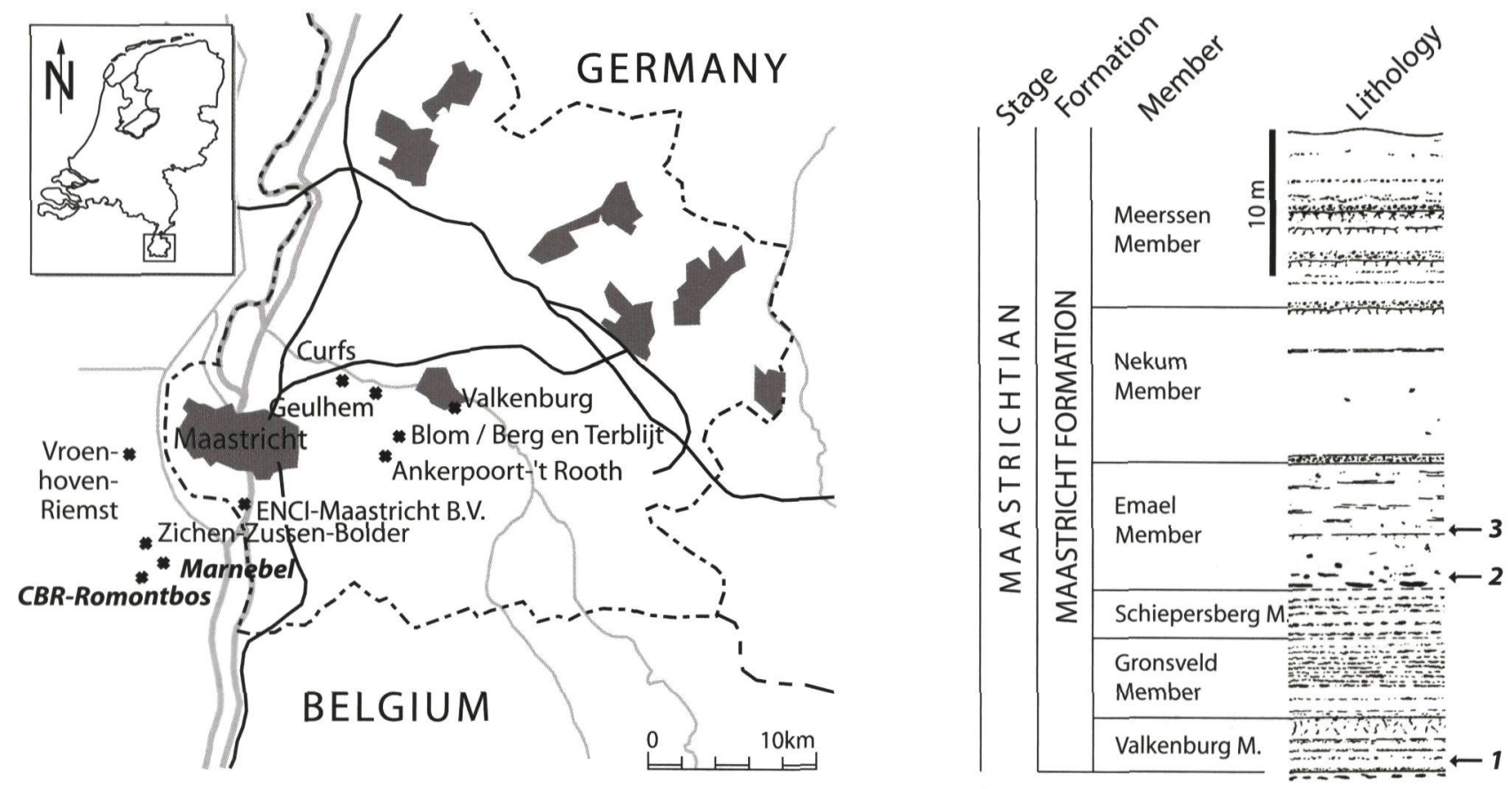

$a$.

b.

Fig. 1. a. Map of the type area of the Maastrichtian Stage; and b. local lithostratigraphy and generalised log (for more details, see Schiøler et al., 1997; Jagt, 1999). Indicated in A are key sections, those having yielding bird remains are bold and italicised; numbered arrows in $B$ show the stratigraphic provenance of bird remains known to date from the area, as follows: $1=$ NHMM RD 271; $2=$ NHMM K 4101; $3=$ NHMM K 4925.

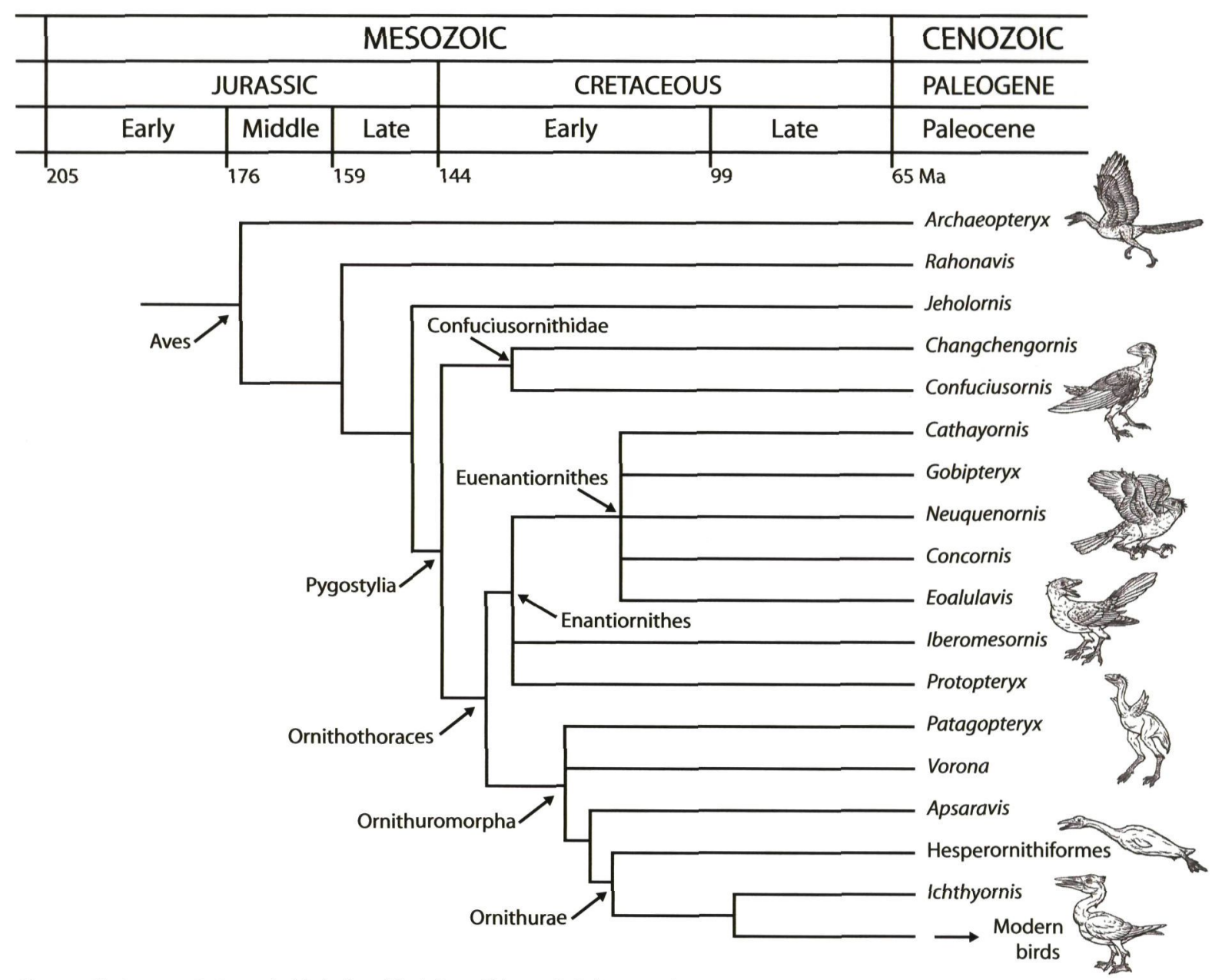

Fig. 2. Cladogram of Mesozoic birds (modified from Chiappe \& Dyke, 2002). 
Walker, 2002), while the Ornithurae includes a number of other well-known, short-tailed birds, particularly well represented in the Cretaceous of Asia (China, Mongolia) and North America (Chiappe \& Dyke, 2002). The sister taxa of the Neornithes are contained within the Ornithurae, and are represented in the Maastrichtian type area (Dyke et al., 2002). All material is housed at the Natuurhistorisch Museum Maastricht (abbreviation NHMM; prefixes RD - R.W. Dortangs Collection; K - M.M.M. Kuypers Collection).

\section{Material}

To date, three fragmentary bird specimens are known from the Maastrichtian type area, as follows:

1. a partial forelimb and skull bones (NHMM RD 271) from the base of the Valkenburg Member (Maastricht Formation) at the CBR-Romontbos quarry (Eben Emael, Liège, northeast Belgium), previously described and illustrated by Dyke et al. (2002);

2. an isolated left tarsometatarsus (NHMM K 4925) from the middle Emael Member (Lava Horizon; Maastricht Formation) at the CBR-Romontbos quarry (Eben Emael);

3. the proximal end of a left radius (NHMM K 4101) from the basal Emael Member (Maastricht Formation) at the Marnebel quarry (Eben Emael).

\section{Systematic palaeontology}

Aves Linnaeus, 1758

Ornithothoraces Chiappe, 1995

Ornithurae Haeckel, 1866

A full description of NHMM RD 271 was provided by Dyke et al. (2002). This partial forelimb skeleton comprises an incomplete right humerus (embedded obliquely such that its cranial surface is visible), the distal end of a right ulna, a scapula blade, as well as portions of the proximal tarsometatarsus and mandible (Fig. 3A). Originally embedded in the same matrix block, but removed during preparation, are the cranial portion of a right coracoid, three isolated thoracic vertebrae and a single, recurved and unserrated tooth (Dyke et al., 2002, fig. 1b-d). Salient features of the anatomy of this ornithurine bird include a rounded, globose head and well-developed deltopectoral crest of the humerus (this crest appears to have extended quite along the length of the humerus), proximal and distal ends that are not offset from one another (Fig. 3A) and a well-developed brachial fossa on the distal humerus. These features support placement of NHMM RD 271 close to the crown of the cladogram (Fig. 2). Other skeletal elements associated in the matrix block with the humerus include the distal end of the right ulna (offset somewhat from its original articulation), part of the blade of the scapula and the shoulder end of the right coracoid. What remains of the ulna is rounded in cross section; the scapula of this bird was distinctly recurved and sagitally tapered as in other ornithurines. The length of this element relative to the humerus cannot be determined. As appears to be typical of nonneornithine Mesozoic birds, the preserved postcranial skeleton of NHMM RD 271 is not particularly pneumatised, with the exception of the vertebral series. The three quite well-preserved mid-series thoracic vertebrae that are part of this specimen have elongate centra perforated on their lateral sides by distinct and large foramina (Dyke et al., 2002, fig. 1b, c). Few other features of phylogenetic interest can be identified. Portions of the left and right mandibular rami are embedded obliquely in the slab, while the preserved dentary appears to be broad and tapers into articulation with an elongate angular (Dyke et al. 2002).

The partial left tarsometatarsus (NHMM K 4925) (Fig. 3B, C) is broken proximally with respect to its three discernible trochlea. The second and fourth digits of this specimen are broken distally such that their trochlea are not preserved; the distal margin of the distal vascular foramen is not preserved either, but its proximal groove is still present. Despite its fragmentary nature, this element displays a number of features that in the literature have been considered phylogenetically informative with respect to basal avians, i.e. the presence of a distinct, single distal vascular foramen and a distally extensive and plantarly displaced third metatarsal (with respect to its preserved counterparts; Fig. 3B, C). Metatarsals II-IV are completely fused and although not completely preserved, it is clear that the distal vascular foramen was enclosed by the third and fourth metatarsals in this specimen. These are characteristic features of ornithuromorph birds (Fig. 2; see Chiappe, 2002). In addition, the medial margin of the third trochlea is indented such that its lateral and medial edges are offset, while its lateral margin extends somewhat further distally. Of these features, one (i.e., plantar displacement of the third metatarsal) is seen, for example, in the genera Yanornis and Apsaravis as well as in more derived ornithurines. Plantar displacement of metatarsal III is also consistent with the ornithurine assignment of this element (see Clarke, 2004). Thus, the overall shape of this tarsometatarsus complies with its placement within Ornithurae, although it is much smaller than its counterpart in NHMM RD 271 (Dyke et al., 2002) and narrower than that of North American Ichthyornis.

The proximal left radius (NHMM $\mathrm{K}$ 4101), seen in dorsal view (Fig. 3D, E), is a robust bone that is broken distally at about one-third of its approximate total length. Cracking of this element distorts the distal dorsal surface, but the humeral cotyla and articulation faces for the ulnaris are clearly visible. On its ventral surface, the shaft of this element bears a distinct longitudinal groove - a characteristic feature seen in a number of euenantiornithines (Chiappe \& Walker, 2002). In addition to this ventral groove, a pair of small bicipital tubercles are also present close to the proximal articulating surface, one above the other; the presence of such tubercles has also been considered characteristic of Enantiornithes (Chiappe \& Walker, 2002). 


\section{Discussion}

\section{Phylogenetic position of birds from the Maastrichtian type area}

Although only a small sample is currently available, the material previously recorded by Dyke et al. (2002) and described herein shows that a reasonably diverse Late Cretaceous avifauna was present in the area. Because the fossil record of Mesozoic avians from marine and marginal marine settings is much more complete than that from terrestrial sediments (Fountaine et al., 2005), we envisage the recovery of much more bird material from this area in future. On the basis of what is available now, strong evidence for the presence of both ornithurines (NHMM RD 271, NHMM K 4925) and enantiornithines (NHMM K 4101) is given. There are few other localities exposing Upper Cretaceous strata that preserve representatives of both clades so close to the $\mathrm{K}-\mathrm{Pg}$ boundary.

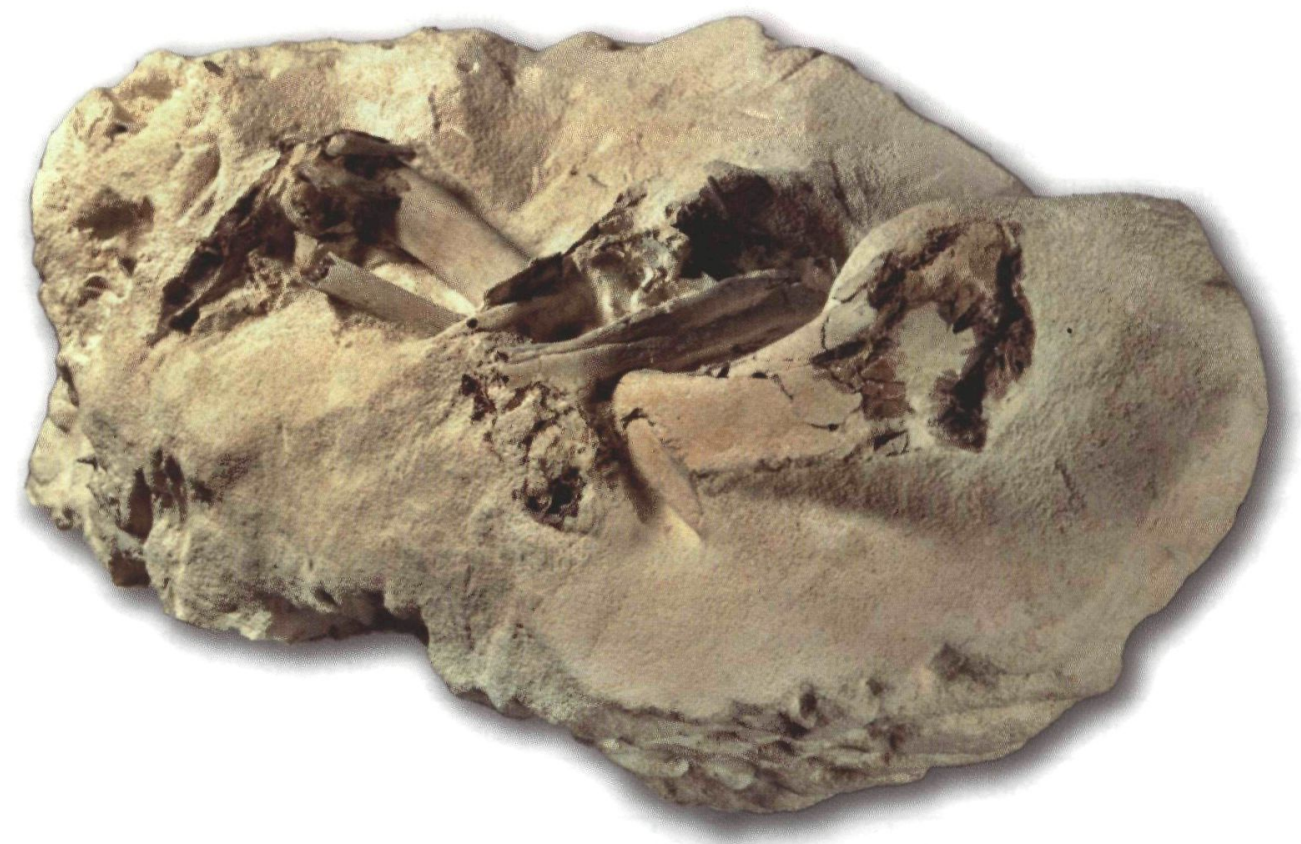

A

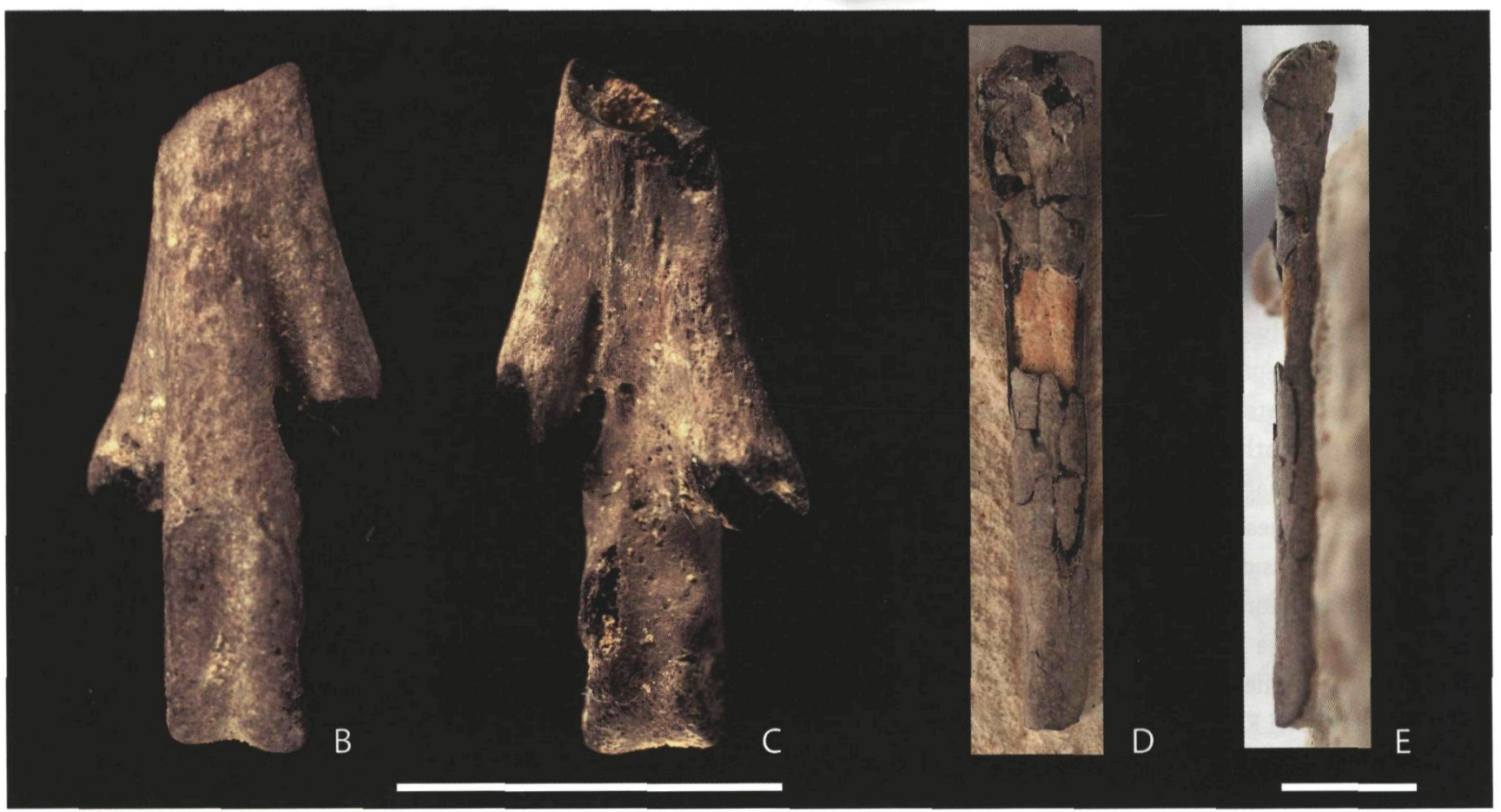

Fig. 3. Avian remains from the Maastrichtian type area; $A$ - NHMM RD 271, base of Valkenburg Member, CBR-Romontbos quarry, Eben Emael (see Dyke et al., 2002); B, C - NHMM K 4925, middle Emael Member, CBR-Romontbos quarry, Eben Emael; tarsometatarsus, in cranial and caudal views, respectively; $D, E-N H M M K$ 4101, base of Emael Member, Marnebel quarry, Eben Emael; proximal left radius. Scale bar equals $10 \mathrm{~mm}$. 
The phylogenetic placement of NHMM RD 271 was assessed by Dyke et al. (2002, p. 408), who, on the basis of a limited set of characters, noted that it should be considered 'closely related' to Ichthyornis. Nevertheless, NHMM RD 271 and the North American Ichthyornis do differ anatomically as well as in size. In spite of its age and potential informativeness, NHMM RD 271 was not included by Clarke (2004) in a more complete anatomical matrix of Aves. Clarke (2004, pp. 14) justified this omission by casting aspersions about the accuracy of the description presented by Dyke et al. (2002) - 'if the description is faithful to the specimen' (Clarke, 2004: p. 14) and 'so far as their meaning (characters) was understood' (Clarke, 2004: p. 15).

However, because NHMM RD 271 is incomplete, and its preserved morphology fragmentary, little additional information can usefully be presented that bears on the relationship of this bird to other ornithurines. We have coded the preserved anatomy of this specimen into more recently published phylogenetic analyses of basal birds (Chiappe, 2002; Clarke, 2004; Clarke et al., 2006) and its placement relative to the avian crown-group (Neornithes) still remains unresolved - within a polytomy alongside Ichthyornis and Neornithes (see Dyke et al., 2002, fig. 1e). The recovery of additional material of this ornithurine taxon from the Maastricht area is required to resolve the issue of its phylogenetic relationships.

\section{Postcranial pneumaticity in Mesozoic birds}

In common with other 'non-neornithine' fossil birds, NHMM RD 271 (along with the other elements known from the Maastrichtian type area) are relatively less pneumatised that their counterpart bones amongst basal modern birds. The humeri, and other appendicular bones, of palaeognaths (Tinamidae) as well as those of Anseriformes ('waterbirds') and Galliformes ('landfowl') are typically perforated by foramina that vary in size ( $0^{\prime}$ Connor, 2004). This reflects perforation of the modern avian axial and appendicular skeleton by air-sacs, a feature considered unique to birds amongst archosaurs (0'Connor, 2006). Perforation of the appendicular skeleton by pneumatic foramina is much less common in basal Cretaceous birds, rarely reported in enantiornithines (Chiappe et al., 2006) and their counterparts, the more phylogenetically crownward ornithurines (Zhou \& Zhang, 2006), except as characters for cladistic analysis (Clarke et al., 2006). Enantiornithines and ornithurines (such as NHMM RD 271) typically have well-developed foramina associated with their vertebrae, but much less so in the bones of the appendicular skeleton. If avian cladograms could be shown to be timecorrelated - in terms of the appearance of clade divergences then increasing pneumatisation of the postcranial skeleton may turn out to be a feature associated with the modern avian radiation across the $\mathrm{K}-\mathrm{Pg}$ boundary.

\section{Acknowledgements}

Our thanks are extended to Rudi Dortangs (Amstenrade) and Marcel Kuypers (Bremen), who collected and recognised the material described here, and to the managements of the CBR-Romontbos, Marnebel, Ankerpoort - 't Rooth and ENCIHeidelbergCement Group quarries, who allowed access to their grounds, which is gratefully acknowledged.

\section{References}

Chiappe, L.M., 1995. The first 85 million years of avian evolution. Nature 378: 349-355.

Chiappe, L.M., 2002. Basal bird phylogeny. Problems and solutions. In: Chiappe, L.M. \& Witmer, L.M. (eds): Mesozoic birds. Above the heads of dinosaurs. University of California Press (Berkeley): 448-472.

Chiappe, L.M. \& Dyke, G.J., 2002. The Mesozoic radiation of birds. Annual Reviews of Ecology and Systematics 33: 91-124.

Chiappe, L.M. \& Walker, C.A., 2002. Skeletal morphology and systematics of the Cretaceous Euenantiornithes (0rnithothoraces: Enantiornithes). In: Chiappe, L.M. \& Witmer, L.M. (eds): Mesozoic birds. Above the heads of dinosaurs. University of California Press (Berkeley): 240-267.

Chiappe, L.M. \& Witmer, L.M., 2002 (eds). Mesozoic birds. Above the heads of dinosaurs. University of California Press (Berkeley): xii + 520 pp.

Chiappe, L.M. Suzuki, S., Dyke, G.J., Watabe, M., Tsogtbaatar \& Barsbold, R., 2006. A new enantiornithine bird from the Late Cretaceous of the Gobi Desert. Journal of Systematic Palaeontology 4(4): 1-16.

Clarke, J.A., 2004. Morphology, phylogenetic taxonomy, and systematics of Ichthyornis and Apatornis (Avialae: Ornithurae). Bulletin of the American Museum of Natural History 286: 1-179.

Clarke, J.A., Zhou, Z. \& Zhang, F., 2006. Insight into the evolution of avian flight from a new clade of Early Cretaceous ornithurines from China and the morphology of Yixianornis grabaui. Journal of Anatomy 208(3): 287-308.

Dyke, G.J., Dortangs, R.W., Jagt, J.W.M., Mulder, E.W.A., Schulp, A.S. \& Chiappe, L.M., 2002. Europe's last Mesozoic bird. Naturwissenschaften 89: 408-411.

Fountaine, T.M.R., Benton, M.J., Dyke, G.J. \& Nudds, R.L., 2005. The quality of the fossil record of Mesozoic birds. Proceedings of the Royal Society of London, Series B (Biological Sciences) 272: 289-294.40.

Haeckel, E., 1866. Generelle Morphologie der Organismen: allgemeine Grundzüge der organischen Formen-Wissenschaft, mechanisch begründet durch die von Charles Darwin reformirte Descendenz-Theorie. Georg Reimer (Berlin): clx + $462 \mathrm{pp}$.

Jagt, J.W.M., 1999. Late Cretaceous-Early Palaeogene echinoderms and the K/T boundary in the southeast Netherlands and northeast Belgium - Part 1: Introduction and stratigraphy. Scripta Geologica 116: 1-57.

Jagt, J.W.M., Mulder, E.W.A., Schulp, A.S., Dortangs, R.W. \& Fraaije, R.H.B. 2003. Dinosaurs from the Maastrichtian-type area (southeastern Netherlands, northeastern Belgium). Comptes Rendus Palevol 2: 67-76.

Linnaeus, C., 1758. Systema naturae, per regna tria naturae, secundum classes, ordines, genera, species, cum characteribus, differentiis, synonymis, locis. Editio decima, reformata 1(6). Laurentii Salvii (Holmiae): iv $+824 \mathrm{pp}$. 
Marsh, O.C., 1880. Odontornithes: a monograph of the extinct toothed birds of North America. Report of the Geological Exploration of the Fortieth Parallel 7: $\mathrm{xv}+201 \mathrm{pp}$

Martin, J.E., Case, J.A., Jagt, J.W.M., Schulp, A.S. \& Mulder, E.W.A., 2005. A new European marsupial indicates a Late Cretaceous high-latitude transatlantic dispersal route. Journal of Mammalian Evolution 12: 495-511.

Mulder, E.W.A., Jagt, J.W.M. \& Schulp, A.S., 2005. Another record of a hadrosaurid dinosaur from the Maastrichtian type area (the Netherlands, Belgium): Seeley (1883) revisited. Bulletin de l'Institut royal des Sciences naturelles de Belgique, Sciences de la Terre 75: 201-206.

O'Connor, J., 2004. Pulmonary pneumaticity in the postcranial skeleton of extant Aves: A case study examining Anseriformes. Journal of Morphology 261(2): 141-161.

o'Connor, J., 2006. Postcranial pneumaticity: An evaluation of soft-tissue influences on the postcranial skeleton and the reconstruction of pulmonary anatomy in archosaurs. Journal of Morphology 267(10): 1199-1226.

Rees, J. \& Lindgren, J., 2005. Aquatic birds from the Upper Cretaceous (lower Campanian) of Sweden and the biology and distribution of hesperornithiforms. Palaeontology 48: 1321-1329.

Schiøler, P., Brinkhuis, H., Roncaglia, L. \& Wilson, G.J., 1997. Dinoflagellate biostratigraphy and sequence stratigraphy of the Type Maastrichtian (Upper Cretaceous), ENCI quarry, the Netherlands. Marine Micropaleontology 31 65-95.

Walker, C.A., 1981. New subclass of birds from the Cretaceous of South America. Nature 292: 51-53.

Zhou, Z. \& Zhang, F., 2006. A beaked basal ornithurine bird (Aves, Ornithurae) from the Lower Cretaceous of China. Zoologica Scripta 35: 363-373. 